\title{
Soil properties determine the elevational patterns of base cations and micronutrients in the plant-soil system up to the upper limits of trees and shrubs
}

\author{
Ruzhen Wang ${ }^{1, *}$, Xue Wang ${ }^{1,2, *}$, Yong Jiang ${ }^{1}$, Artemi Cerdà ${ }^{3}$, Jinfei Yin ${ }^{1}$, Heyong Liu ${ }^{1}$, Xue Feng ${ }^{1}$, Zhan Shi $^{1}$, \\ Feike A. Dijkstra ${ }^{4}$, and Mai-He $\mathrm{Li}^{1,5}$ \\ ${ }^{1}$ State Engineering Laboratory of Soil Nutrient Management, Institute of Applied Ecology, \\ Chinese Academy of Sciences, Shenyang 110016, China \\ ${ }^{2}$ Zhejiang Provincial Key Laboratory of Plant Evolutionary Ecology and Conservation, \\ Taizhou University, Taizhou 318000, China \\ ${ }^{3}$ Soil Erosion and Degradation Research Group, Department of Geography, University of Valencia, Valencia, Spain \\ ${ }^{4}$ Sydney Institute of Agriculture, School of Life and Environmental Sciences, The University of Sydney, \\ Sydney, NSW 2006, Australia \\ ${ }^{5}$ Forest dynamics, Swiss Federal Research Institute WSL, Zuercherstrasse 111, 8903 Birmensdorf, Switzerland \\ *These authors contributed equally to this work.
}

Correspondence: Yong Jiang (jiangyong@iae.ac.cn)

Received: 13 July 2017 - Discussion started: 4 August 2017

Revised: 11 February 2018 - Accepted: 2 March 2018 - Published: 26 March 2018

\begin{abstract}
To understand whether base cations and micronutrients in the plant-soil system change with elevation, we investigated the patterns of base cations and micronutrients in both soils and plant tissues along three elevational gradients in three climate zones in China. Base cations $(\mathrm{Ca}, \mathrm{Mg}$, and $\mathrm{K})$ and micronutrients ( $\mathrm{Fe}, \mathrm{Mn}$, and $\mathrm{Zn}$ ) were determined in soils, trees, and shrubs growing at lower and middle elevations as well as at their upper limits on Balang (subtropical, SW China), Qilian (dry temperate, NW China), and Changbai (wet temperate, NE China) mountains. No consistent elevational patterns were found for base cation and micronutrient concentrations in both soils and plant tissues (leaves, roots, shoots, and stem sapwood). Soil $\mathrm{pH}$, soil organic carbon (SOC), total soil nitrogen ( $\mathrm{TN}$ ), the $\mathrm{SOC}$ to $\mathrm{TN}$ ratio $(\mathrm{C}: \mathrm{N})$, and soil extractable nitrogen $\left(\mathrm{NO}_{3}^{-}\right.$and $\left.\mathrm{NH}_{4}^{+}\right)$determined the elevational patterns of soil exchangeable $\mathrm{Ca}$ and $\mathrm{Mg}$ and available $\mathrm{Fe}, \mathrm{Mn}$, and $\mathrm{Zn}$. However, the controlling role of soil $\mathrm{pH}$ and $\mathrm{SOC}$ was not universal as revealed by their weak correlations with soil base cations under tree canopies at the wet temperate mountain and with micronutrients under both tree and shrub canopies at the dry temperate mountain. In most cases, soil base cation and micronutrient availabilities played fundamental roles in determining the
\end{abstract}

base cation and micronutrient concentrations in plant tissues. An exception existed for the decoupling of leaf $\mathrm{K}$ and $\mathrm{Fe}$ with their availabilities in the soil. Our results highlight the importance of soil physicochemical properties (mainly SOC, $\mathrm{C}: \mathrm{N}$, and $\mathrm{pH}$ ) rather than elevation (i.e., canopy cover and environmental factors, especially temperature), in determining base cation and micronutrient availabilities in soils and subsequently their concentrations in plant tissues.

\section{Introduction}

Base cations and micronutrients are essential for soil fertility and plant physio-ecological processes of photosynthesis, metabolism, growth, and productivity (Salisbury and Ross, 1992). For instance, exchangeable calcium (Ca) and magnesium $(\mathrm{Mg})$ are predominant base cations responsible in buffering soil acidity, and deficiency of these nutrients can occur in terrestrial ecosystems (Naples and Fisk, 2010; Baribault et al., 2012; Sardans and Peñuelas, 2015), particularly when they are exposed to acid rain. Micronutrient deficiency, on the other hand, occurs more frequently, 
for instance, when replenishment of micronutrients via litter decomposition does not keep pace with output processes of plant uptake and leaching (White and Zasoski, 1999; Hernandez-Apaolaza, 2014). High soil pH can limit the availability of micronutrients of iron $(\mathrm{Fe})$, manganese (Mn), and zinc (Zn; Reisenauer, 1988; Lucena, 2000; Rengel, 2007), while low soil $\mathrm{pH}$ can induce toxicities of trace metals constraining terrestrial net primary productivity (He et al., 2005; Reisenauer, 1988; Tian et al., 2016). The concentrations of soil base cations and available micronutrients were suggested to be positively and negatively correlated with soil $\mathrm{pH}$, respectively, but both positively correlated with soil organic matter (SOM) concentration (Reisenauer, 1988; Wang et al., 2017). Concentrations of base cation and micronutrient can differ among plant tissues as a result of their slow translocation from the roots to the canopy (van der Heijden et al., 2015), distinct mobility among plant tissues (Warnock, 1970), and occurrence of remobilization during different physiological stages (Maillard et al., 2015). Quantifying base cation and micronutrient concentrations in soils and plant tissues (leaves, roots, shoots, and stems) can help explain the nutritional status and potential deficiencies of micronutrients during plant growth (Richardson, 2004). However, little attention has been paid to base cation and micronutrient availabilities in soils as well as their variations among plant roots, leaves, shoots, and stem sapwood under changing environmental conditions (Rengel, 2007).

The plant distribution and growth along elevational gradients reflect changes in environmental conditions ( $\mathrm{Li}$ and Yang, 2004; Li et al., 2003, 2006, 2008a, b; Zhu et al., 2012a, b). Plants growing at high elevation, especially close to their upper limits, are expected to be highly sensitive to climate change, in particular to global warming (Noble, 1993). Physiological studies of tree line trees have mainly focused on macronutrients such as nitrogen $(\mathrm{N})$, phosphorus $(\mathrm{P})$, and Ca (Richardson, 2004; Liptzin et al., 2013; Mayor et al., 2017), while there are few data available for micronutrients in plant-soil systems along elevational gradients (Wang et al., 2009). Two hypotheses have been proposed to explain nutrient accumulation and/or nutrient deficiency in plant tissues at high elevations (Oleksyn et al., 2002; Richardson, 2004). First, the decrease in temperature with increasing elevation declines soil microbial activity and plant metabolism, and thus constrains soil nutrient cycling and plant uptake processes (Körner and Paulsen, 2004; Thébault et al., 2014). At the alpine tree line, low temperature slows down microbialmediated litter decomposition and thus reduces nutrient supply to plants (van den Driessche, 1974; Richardson, 2004). Second, another paradigm exists that plants retain higher nutrient concentrations in their tissues to maintain metabolic capacity and to avoid cold injury at higher elevations with cold growth conditions (Oleksyn et al., 2002). These two hypotheses are mainly tested on tree line trees, and little attention has been put on other plant types, such as shrub line shrubs. Whether trees and shrubs growing at high elevations have higher or lower base cation and micronutrient concentrations is still unclear.

The change in environmental conditions along elevational gradients, including temperature and growing season length (Barry, 1981), provides a unique opportunity to examine the spatial distribution of base cations and micronutrients in plant-soil systems. Uncertainties still exist whether soil properties or environmental factors determine the base cations and micronutrients in plant-soil systems. Therefore, we studied the base cation $(\mathrm{Ca}, \mathrm{Mg}$, and $\mathrm{K}$ ) and micronutrient $(\mathrm{Fe}, \mathrm{Mn}$, and $\mathrm{Zn})$ concentrations in plant-soil systems along elevational gradients up to the alpine tree and shrub line in subtropical, dry temperate, and wet temperate climate zones in China. Soil base cation and micronutrient concentrations can increase through soil weathering and decomposition of organic matter, but can decrease with plant uptake and loss through leaching. We therefore hypothesized that soil base cation and micronutrient concentrations increase with increasing elevation because plant uptake decreases more than the supply through weathering and decomposition with elevation. We also expected that plants of both trees and shrubs at higher elevations would have greater base cation and micronutrient concentrations in their tissues (leaves, roots, shoots, and stem sapwood) to maintain physioecological processes in a colder environment. To test these hypotheses, we collected soil and plant samples along three elevational gradients from lower elevations up to the alpine tree line or shrub line in three climate zones in China, and studied the $\mathrm{Ca}, \mathrm{Mg}, \mathrm{K}, \mathrm{Fe}, \mathrm{Mn}$, and $\mathrm{Zn}$ concentrations in plant-soil systems.

\section{Materials and methods}

\subsection{Site description and sample collection}

Study sites were located in three climate zones (summarized in Table S1 in the Supplement): Balang Mountain with a subtropical climate located in Wolong Nature Reserve ("subtropical mountain"; $102^{\circ} 52^{\prime}-103^{\circ} 24^{\prime} \mathrm{E}, 30^{\circ} 45^{\prime}-31^{\circ} 25^{\prime} \mathrm{N}$ ) in southwestern China, Qilian Mountains located in the dry temperate climate zone (“dry temperate mountain"; $102^{\circ} 58^{\prime}-$ $103^{\circ} 01^{\prime} \mathrm{E}, 37^{\circ} 14^{\prime}-37^{\circ} 20^{\prime} \mathrm{N}$ ) in northwestern China, and Changbai Mountains with a wet temperate climate ("wet temperate mountain"; $126^{\circ} 55^{\prime}-129^{\circ} 00^{\prime} \mathrm{E}, 41^{\circ} 23^{\prime}-42^{\circ} 36^{\prime} \mathrm{N}$ ) located in northeastern China (see Fig. S1). Three distinct sites were chosen to find the general patterns for base cations and micronutrients along elevational gradients across climate scales rather than to investigate the comparability among study sites. The subtropical mountain is influenced by warm wet monsoon masses in summer and continental air masses in winter (Li et al., 2012). The mean annual precipitation (MAP) of the subtropical mountain is about $846 \mathrm{~mm}$ monitored by Dengsheng Meteorological Station at $2730 \mathrm{~m}$ (Li et al., 2012). For the dry temperate mountain, the MAP is 
$435 \mathrm{~mm}$, which is monitored by the Qilian weather station at $2787 \mathrm{~m}$ altitude (Qiang et al., 2003). The wet temperate mountain is located in a typical continental temperate monsoon climate zone with MAP increasing from 632 to $1154 \mathrm{~mm}$ along the elevational gradient from 530 to $2200 \mathrm{~m}$ (Shen et al., 2013).

In this study, the alpine tree and shrub lines are defined as the upper limit of obvious trees and shrubs, respectively. The trees that were investigated are Abies faxoniana (elevation range $2860-3670 \mathrm{~m}$ ) for the subtropical mountain, Picea crassifolia (elevation range 2540-3250 m) for the dry temperate mountain, and Betula ermanii (elevation range $1700-2030 \mathrm{~m}$ ) for the wet temperate mountain. The shrubs are Quercus aquifolioides (elevation range 2840-3590 m) for the subtropical, Salix gilashanica (elevation range 3020$3540 \mathrm{~m}$ ) for the dry temperate, and Vaccinium uliginosum (elevation range $1430-2380 \mathrm{~m}$ ) for the wet temperate mountain. The targeted tree line trees and shrub line shrubs are dominant and common species for each study site. The soils from the three sampling sites of subtropical, dry temperate, and wet temperate mountain zones were classified as Umbric Cryic Cambisols, Calcaric Ustic Cambisols, and Andic Gelic Cambisols, respectively (IUSS Working Group WRB, 2014).

Plant tissue samples of current-year mature leaves, roots $(<2 \mathrm{~mm})$, stem sapwood, and shoots (twigs) from trees and shrubs were collected at the lower and middle elevations, and at the upper limits. At each elevation, six independent plots $(10 \mathrm{~m} \times 10 \mathrm{~m})$ were selected to serve as six replicates on southern slopes with $25 \mathrm{~m}$ distance between adjacent plots. Within each plot, 6-10 trees or shrubs of similar height were randomly selected for tissue sampling. Sampling elevations for trees and shrubs were different for each site (Table S1). Soils $(0-10 \mathrm{~cm})$ were directly collected under the canopy of trees or shrubs sampled for each plot using a $3 \mathrm{~cm}$ diameter corer. Both plant and soil samples were homogenized and composited within each plot. Samples were collected at the middle of July for subtropical mountain, at the beginning of August for dry temperate mountain, and at end of August for wet temperate mountain in 2014. The main characteristics of the three study sites are summarized in Table S1.

\subsection{Chemical analysis}

The soil samples were separated into two subsamples with one subsample being air-dried to constant weight and the other one stored at $4{ }^{\circ} \mathrm{C}$ for further analyses. For subtropical and wet temperate mountain zones, soil organic carbon (SOC), and total nitrogen (TN) were determined on ground soils using an elemental analyzer (Vario MACRO Cube, Elementar, Germany). For dry temperate mountain, the ground soil samples were treated with $12 \mathrm{M} \mathrm{HCl}$ according to Wang et al. (2015) to remove inorganic $\mathrm{C}$ before organic $\mathrm{C}$ determination on the elemental analyzer. Soil $\mathrm{NO}_{3}^{-}-\mathrm{N}$ and $\mathrm{NH}_{4}^{+}$$\mathrm{N}$ were extracted from fresh soils with a $2 \mathrm{M} \mathrm{KCl}$ solution and measured using the Continuous-Flow AutoAnalyzer III
(Bran \& Luebbe, Norderstedt, Germany). Soil total inorganic nitrogen (TIN) was the sum of extractable $\mathrm{NO}_{3}^{-}-\mathrm{N}$ and $\mathrm{NH}_{4}^{+}$$\mathrm{N}$. Soil Olsen phosphorus (P) was quantified by colorimetric analysis after extraction with a $0.5 \mathrm{M} \mathrm{NaHCO}_{3}$ solution (Olsen et al., 1954).

A subsample of $5 \mathrm{~g}$ soil was used to determine soil $\mathrm{pH}$ in a $1: 5(w / v)$ soil-to-water suspension. Soil exchangeable base cations were extracted with a $1 \mathrm{M}$ ammonium acetate solution (Wang et al., 2017). Soil-available micronutrients were extracted using diethylenetriamine pentaacetic acid (DTPA) according to Lü et al. (2016). Briefly, $10 \mathrm{~g}$ of soil was extracted using $20 \mathrm{~mL} 0.005 \mathrm{M} \mathrm{DTPA}+0.01 \mathrm{M} \mathrm{CaCl}_{2}+0.1 \mathrm{M}$ TEA (triethanolamine; pH 7.0). The soil-solution suspension was shaken for $2 \mathrm{~h}$ at $180 \mathrm{rpm}$ and then filtered through ash-free filter paper. The concentrations of base cations and micronutrients were determined using an atomic absorption spectrometer (AAS, Shimadzu, Japan).

Plant samples of leaves, roots, shoots, and stem sapwood were oven-dried at $60^{\circ} \mathrm{C}$ for $48 \mathrm{~h}$ and ground for base cation and micronutrient analyses. Root samples were washed prior to being oven-dried. To determine total base cation and trace element concentrations, $0.2 \mathrm{~g}$ plant samples were digested with a mixture of acids of $\mathrm{HNO}_{3}$ and $\mathrm{HClO}_{4}(5: 1, v / v)$ on a hot plate. After the mixture turned into clear solution, the digests were decanted into $50 \mathrm{~mL}$ volumetric flasks and the volume was adjusted to $50 \mathrm{~mL}$. The concentrations of $\mathrm{Ca}$, $\mathrm{Mg}, \mathrm{K}, \mathrm{Fe}, \mathrm{Mn}$, and $\mathrm{Zn}$ were determined by the AAS (Shimadzu, Japan).

\subsection{Statistical analyses}

Normality of data was determined using the KolmogorovSmirnov test, and homogeneity of variances using Levene's test. Generalized linear mixed models (GLMMs) were executed to determine the effects of plant type (tree or shrub), elevation position, and their interactions on soil $\mathrm{pH}, \mathrm{SOC}$, soil exchangeable base cations and available micronutrients, and total base cations and micronutrients in plant tissues. We assigned sampling site to be a random factor in the statistics, as this study aimed to test the general elevational patterns instead of site-specific heterogeneity of base cations and micronutrients in plant-soil system across three sites. The GLMMs were run using $\mathrm{R}$ version 3.2 .3 (http://www. r-project.org, last access: February 2018).

Within each site, the effect of elevation on measured parameters was determined by multiple comparisons with Duncan's multiple range test for soils and each plant type. Pearson correlation analysis was performed to determine the relationships between measured parameters using SPSS 16.0 (SPSS, Inc., Chicago, IL, USA). The soil pH, SOC, TN, ratio of SOC to $\mathrm{TN}(\mathrm{C}: \mathrm{N}), \mathrm{NH}_{4}^{+}$, and Olsen $\mathrm{P}$ were analyzed as factors explaining the variability of soil base cation and micronutrient concentrations by structural equation modeling (SEM). Before constructing models, simple linear regressions between all parameters were examined in order to se- 
Table 1. Effects ( $F$ values) of plant type ( $L$, tree or shrub), elevation position $(E)$, and their interactions on soil pH, soil organic carbon (SOC), base cations and micronutrients in soils (exchangeable/available form), and plants (total) across sampling sites.

\begin{tabular}{lrrrrrrrrrrrrrrrrrrrr}
\hline & soil $\mathrm{pH}$ & SOC & soil Ca & soil Mg & soil K & leaf Ca & root Ca & shoot Ca & stem Ca & leaf Mg & root Mg & shoot Mg & stem Mg & leaf K & root K & shoot K \\
\hline$L$ & $19.6^{\mathrm{b}}$ & 0.96 & $4.72^{\mathrm{a}}$ & $5.85^{\mathrm{a}}$ & $35.8^{\mathrm{b}}$ & 3.05 & $14.7^{\mathrm{b}}$ & $20.20^{\mathrm{b}}$ & $21.9^{\mathrm{b}}$ & $16.5^{\mathrm{b}}$ & 0.09 & $17.1^{\mathrm{b}}$ & $42.6^{\mathrm{b}}$ & $5.98^{\mathrm{a}}$ & 1.42 & $26.4^{\mathrm{b}}$ \\
$E$ & $5.37^{\mathrm{b}}$ & $12.0^{\mathrm{b}}$ & 0.25 & 0.61 & $21.4^{\mathrm{b}}$ & $9.10^{\mathrm{b}}$ & $6.98^{\mathrm{b}}$ & $14.5^{\mathrm{b}}$ & 0.00 & 1.66 & 0.49 & $6.82^{\mathrm{b}}$ & $3.86^{\mathrm{a}}$ & $8.08^{\mathrm{b}}$ & 0.67 & 2.16 \\
$L \times E$ & $15.6^{\mathrm{b}}$ & $3.33^{\mathrm{a}}$ & 2.40 & 0.55 & $8.61^{\mathrm{b}}$ & 2.24 & $8.55^{\mathrm{b}}$ & $6.61^{\mathrm{b}}$ & 1.11 & 1.82 & $7.20^{\mathrm{b}}$ & $5.23^{\mathrm{b}}$ & 0.37 & 0.95 & 1.01 & 2.20 \\
\hline & stem K & soil Fe & soil Mn & soil Zn & leaf Fe & root Fe & shoot Fe & stem Fe & leaf Mn & root Mn & shoot Mn & stem Mn & leaf Zn & root Zn & shoot Zn & stem Zn \\
\hline$L$ & $28.9^{\mathrm{b}}$ & 2.65 & 0.10 & $4.71^{\mathrm{a}}$ & $15.8^{\mathrm{b}}$ & 2.84 & $4.44^{\mathrm{a}}$ & $5.41^{\mathrm{a}}$ & 0.11 & 2.41 & $7.45^{\mathrm{b}}$ & $18.0^{\mathrm{b}}$ & 3.03 & $5.10^{\mathrm{a}}$ & 2.63 & $14.5^{\mathrm{b}}$ \\
$E$ & $3.36^{\mathrm{a}}$ & $3.22^{\mathrm{a}}$ & 0.15 & 2.07 & 0.20 & $5.08^{\mathrm{b}}$ & $3.46^{\mathrm{a}}$ & 0.66 & $4.45^{\mathrm{a}}$ & 0.91 & 0.14 & 1.72 & 1.47 & 0.16 & 1.31 & 0.40 \\
$L \times E$ & 2.84 & 0.05 & 1.69 & $4.42^{\mathrm{a}}$ & 0.36 & $3.40^{\mathrm{a}}$ & $3.72^{\mathrm{a}}$ & 0.61 & 0.15 & 2.81 & 1.22 & 2.37 & 0.90 & 1.93 & 1.34 & 2.12 \\
\hline
\end{tabular}

${ }^{\mathrm{a}}$ and ${ }^{\mathrm{b}}$ indicate significant levels at $P<0.05$ and 0.01 , respectively.

lect factors explaining the maximum variability. The SEM analyzed the direct, indirect and total effect of soil parameters on targeted variables. We fitted the models using $\mathrm{R}$ statistics and determined the best-fit models using Akaike information criteria. Statistical significance was accepted at $P<0.05$ for all the analyses.

\section{Results}

\subsection{Soil pH and SOC}

Soil $\mathrm{pH}$ was significantly different among elevational positions (Table 1). For both subtropical and dry temperate mountain zones, soil $\mathrm{pH}$ decreased with increasing elevation under tree canopy, while it was the opposite trend under shrub canopy (Fig. 1a). For wet temperate mountain, the upper limit of shrubs had significantly higher soil pH (Fig. 1a).

For all three sites, SOC concentration showed a humpshaped trend with the highest value at the middle elevation under tree canopy (Fig. 1b). Under shrubs, SOC concentration significantly increased with increasing elevation for subtropical and wet temperate mountain zones, while it was the lowest at the upper limit of shrubs for dry temperate mountain (Fig. 1b).

\subsection{Changes in soil base cations and available micronutrients}

Soil exchangeable $\mathrm{Ca}$ and $\mathrm{Mg}$ decreased with increasing elevation under tree canopy of subtropical and wet temperate mountain zones and under shrubs of dry temperate mountain (except for Mg; Fig. 2a, b). However, they showed the opposite trend under shrubs of subtropical (except for $\mathrm{Mg}$ ) and wet temperate mountain zones and under trees of dry temperate mountain (Fig. 2a, b). Soil exchangeable K decreased with increasing elevation under tree and shrub canopies at subtropical mountain and under trees at dry temperate mountain (Fig. 2c).

Soil-available Fe was significantly affected by elevation position (Table 1 and Fig. 2d). The upper limit had the lowest concentration under both tree and shrub canopies for subtropical mountain and under shrub canopy for wet temper-

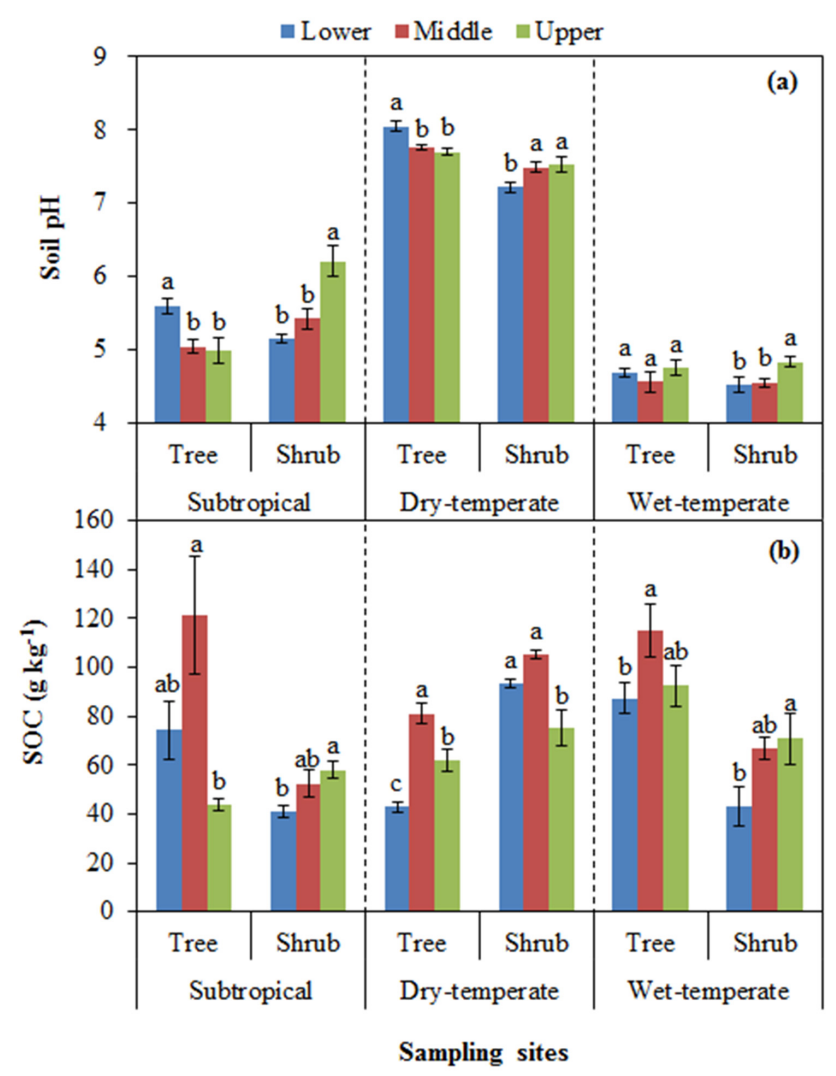

Figure 1. Soil pH values (a) and soil organic carbon (SOC) concentration (b) at lower and middle elevations as well as at the upper limit of tree and shrub lines for each of the three sites. Different letters indicate significant differences among three elevations within tree and shrub lines for each site.

ate mountain (Fig. 2d). For dry temperate mountain, soilavailable Fe significantly increased with increasing elevation under both tree and shrub canopies (Fig. 2a). For subtropical mountain, soil-available Mn was significantly higher at the middle elevation under tree canopies. Soil-available Mn decreased with increasing elevation under shrub and tree canopies for subtropical and wet temperate mountain zones, respectively, while it showed the opposite trend under both tree and shrub canopies of dry temperate mountain and under 

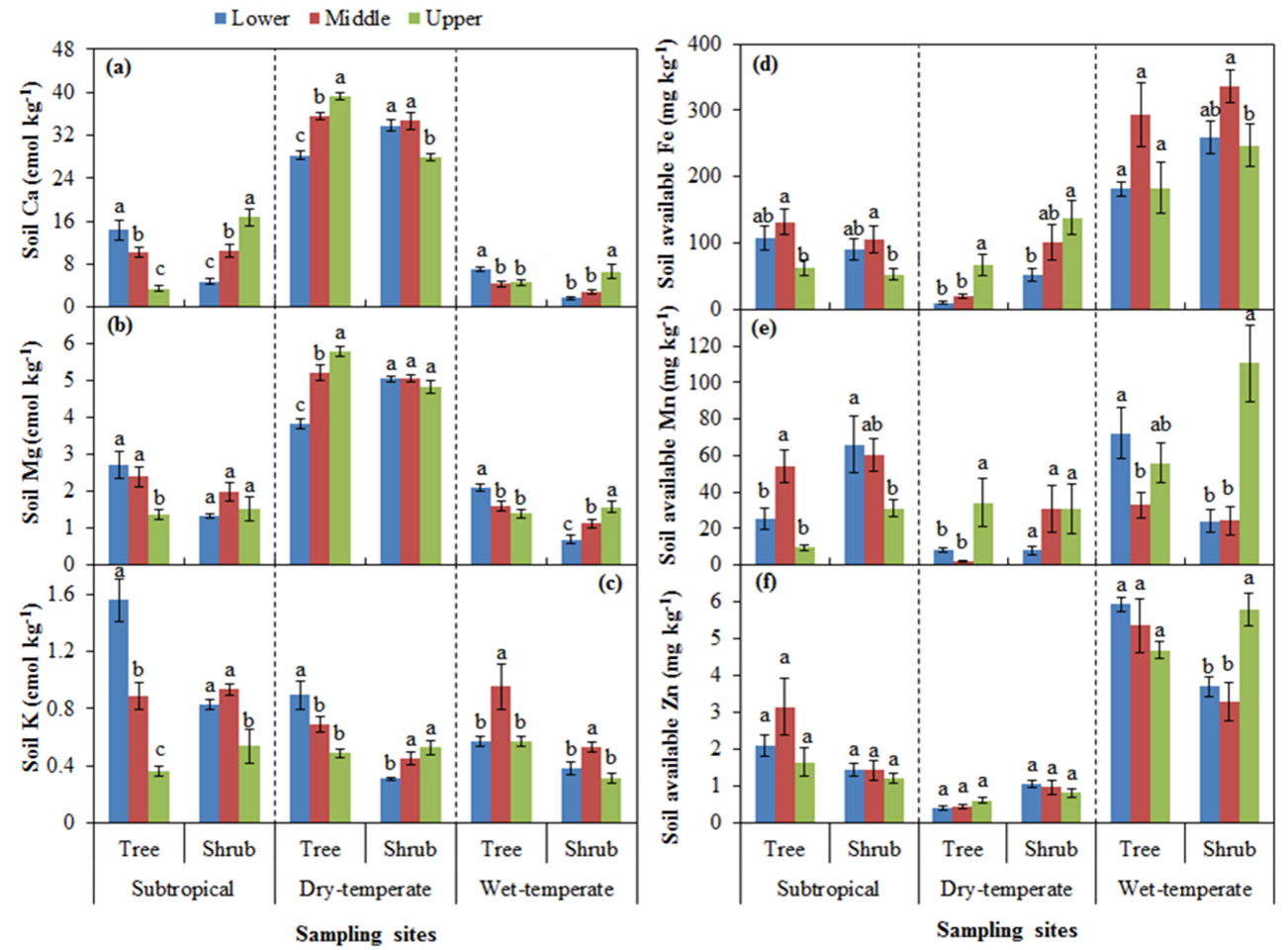

Figure 2. Concentrations of soil exchangeable base cations of $\mathrm{Ca}(\mathbf{a}), \mathrm{Mg}(\mathbf{b})$ and $\mathrm{K}$ (c) and available micronutrients of Fe (d), $\mathrm{Mn}$ (e), and $\mathrm{Zn}$ (f) at lower and middle elevations as well as at the upper limit of trees and shrubs for each of the three sites. Different letters indicate significant differences among three elevations within tree and shrub lines for each site.

shrubs of wet temperate mountain (Fig. 2e). Soil-available $\mathrm{Zn}$ was significantly affected by plant type and the interactive effect between plant type and elevation position (Table 1). Specifically, soils at the upper limit had the highest available $\mathrm{Zn}$ under shrubs at wet temperate mountain.

\subsection{Base cations in plants}

For subtropical mountain, a significant decrease in Ca concentration was detected in the leaves of trees and shrubs (Fig. 3a), roots and shoots of trees (Fig. 3b, c), and stem sapwood of shrubs with increasing elevation (Fig. 3d). For dry temperate mountain, $\mathrm{Ca}$ concentration decreased with increasing elevation in roots, shoots, and stem sapwood of trees (Fig. 3b, c, d), and in shoots and stem sapwood of shrubs (Fig. 3c, d). For wet temperate mountain, shoot Ca concentration decreased with increasing elevation for trees (Fig. 3c). Along with increasing elevation, a significant decrease in $\mathrm{Mg}$ was found in shrub leaves, tree roots, shrub shoots, and stem sapwood at subtropical mountain (Fig. 3e, f, g, h), and in roots, shoots, and stem sapwood of trees at dry temperate mountain (Fig. 3f, g, h), and in leaves and shoots of both trees and shrubs at wet temperate mountain (Fig. 3e, g). With the increase in elevation, $\mathrm{K}$ concentration significantly decreased in leaves of trees, roots, and stem sapwood of both trees and shrubs at subtropical mountain (Fig. 3i, j, l), in tree shoots of dry temperate mountain (Fig. 3k), and in leaves of both trees and shrubs at wet temperate mountain (Fig. 3i).

\subsection{Micronutrients in plants}

For subtropical mountain, $\mathrm{Fe}$ concentrations in leaves (Fig. 4a) and roots (Fig. 4b) showed a similar trend with soil-available $\mathrm{Fe}$, with the highest values at the middle elevation for both trees and shrubs. For dry temperate mountain, the highest $\mathrm{Fe}$ concentrations were found at the lower elevation in leaves (Fig. 4a), roots (Fig. 4b), shoots (Fig. 4c), and stem sapwood (Fig. 4d) for trees, and in shoots (Fig. 4c) and stem sapwood (Fig. 4d) for shrubs. For wet temperate mountain, $\mathrm{Fe}$ concentration was the highest in tree shoots at the middle elevation (Fig. 4c), in shrub leaves at lower elevation (Fig. 4a), and in roots, shoots, and stem sapwood of shrubs at the upper limit of trees (Fig. 4b, c, d).

The Mn concentration decreased with increasing elevation in leaves and shoots of both trees and shrubs at subtropical mountain (Fig. 4e, g), in stem sapwood of shrubs at both subtropical and dry temperate mountain zones (Fig. 4h). The Mn concentration increased with increasing elevation in leaves of trees at dry temperate mountain (Fig. 4e), in roots of both trees and shrubs at wet temperate mountain (Fig. 4f), and in shoots of shrubs and stem sapwood of trees and shrubs at wet temperate mountain (Fig. 4g, h). 

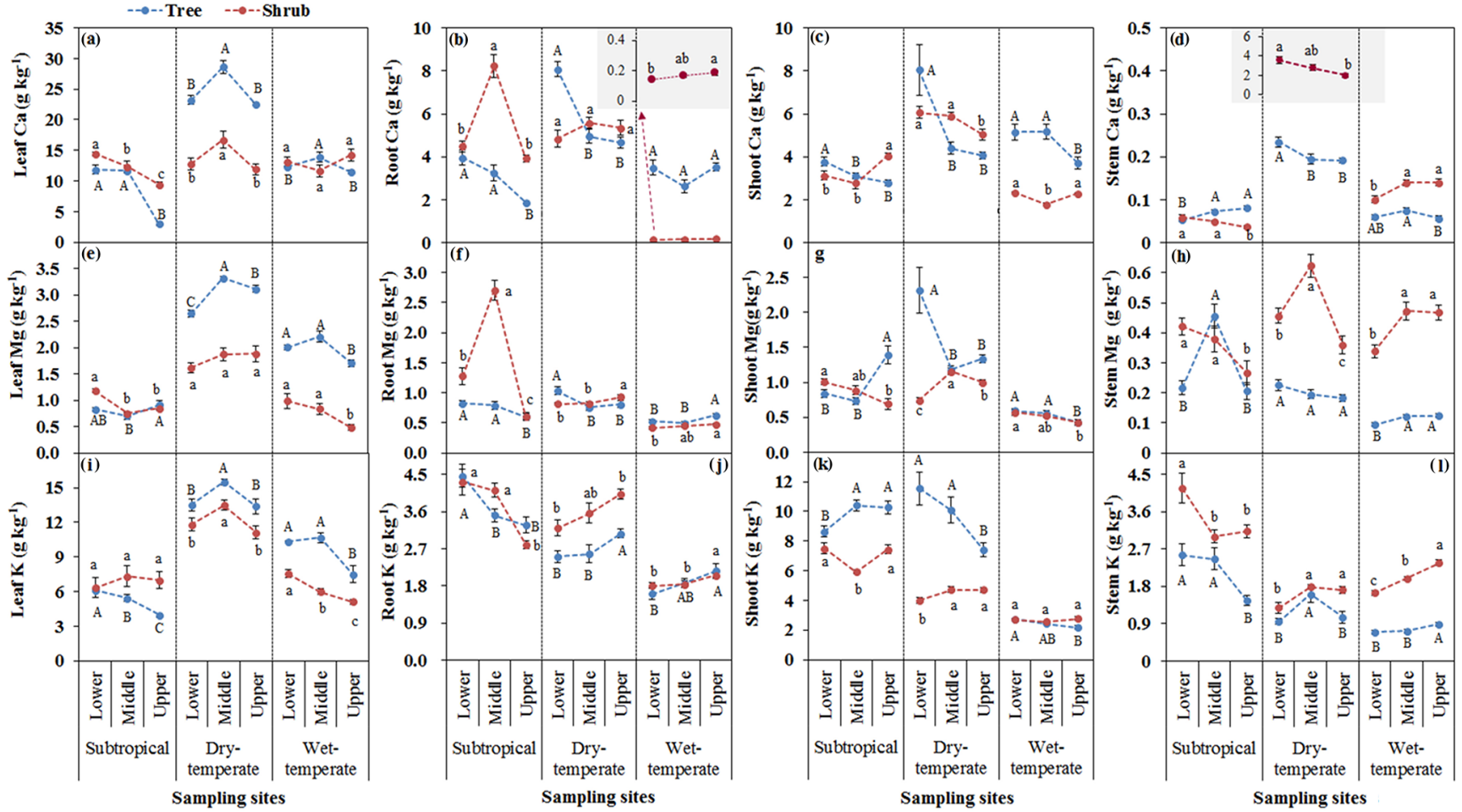

Figure 3. Base cation concentrations of $\mathrm{Ca}(\mathbf{a}, \mathbf{b}, \mathbf{c}, \mathbf{d}), \mathrm{Mg}(\mathbf{e}, \mathbf{f}, \mathbf{g}, \mathbf{h})$ and $\mathrm{K}(\mathbf{i}, \mathbf{j}, \mathbf{k}, \mathbf{l})$ in plant tissues of leaf, root, shoot, and stem sapwood at lower and middle elevations as well as at the upper limit of trees and shrubs for each of the three sites. Different letters indicate significant differences among three elevations within tree and shrub lines for each site.
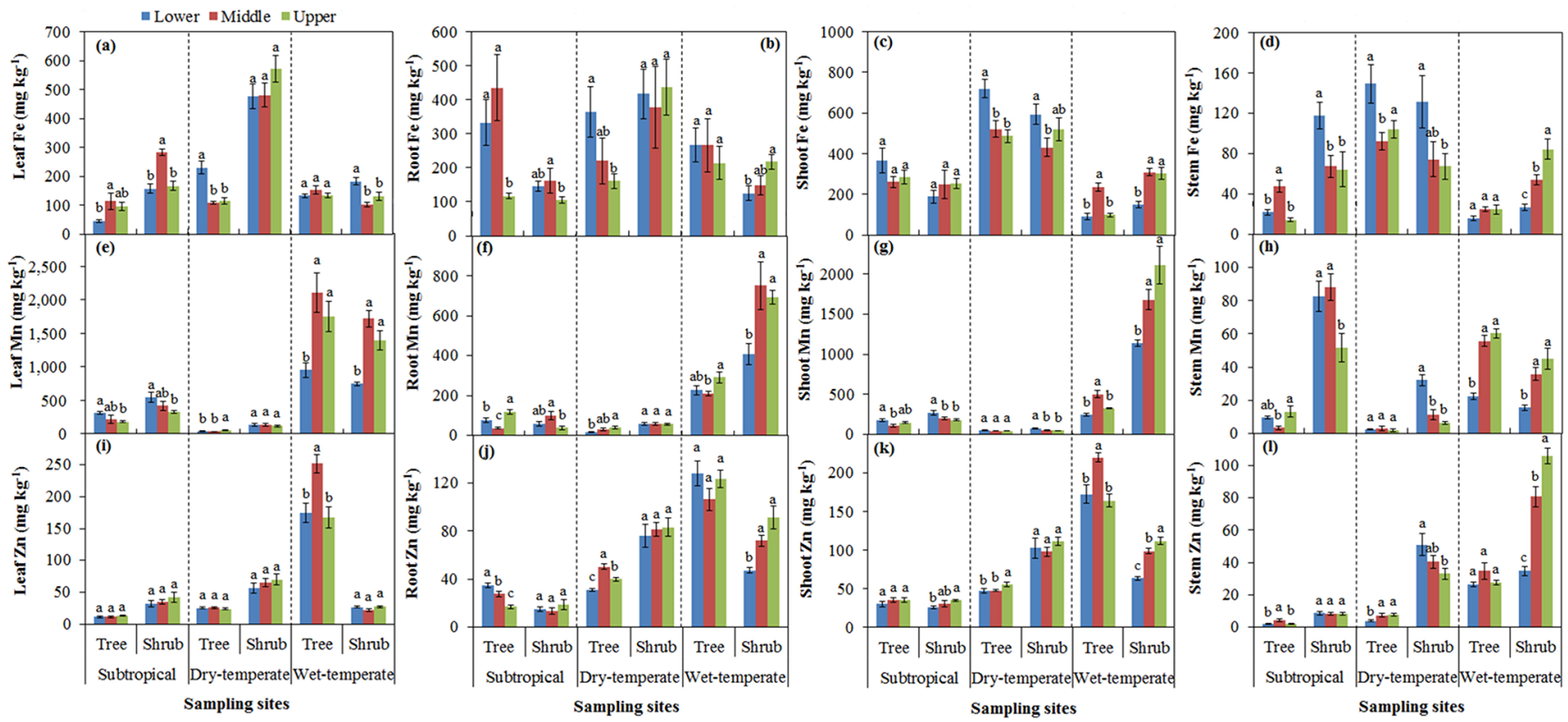

Figure 4. Micronutrient concentrations of Fe (a, b, c, d), Mn (e, f, g, h), and Zn (i, j, k, l) in plant tissues of leaf, root, shoot, and stem sapwood at lower and middle elevations as well as at the upper limit of trees and shrubs for each of the three sites. Different letters indicate significant differences among three elevations within tree and shrub lines for each site. 
Table 2. Regression statistics relating soil base cations and micronutrients to other soil physicochemical parameters under all trees and shrubs across three sampling sites. The TN, C:N, TIN, and Olsen P represent soil total nitrogen, SOC to TN ratio, total inorganic nitrogen, and Olsen phosphorus.

\begin{tabular}{lrrrrrr}
\hline & $\mathrm{Ca}$ & $\mathrm{Mg}$ & $\mathrm{K}$ & $\mathrm{Fe}$ & $\mathrm{Mn}$ & $\mathrm{Zn}$ \\
\hline $\mathrm{pH}$ & $0.94^{\mathrm{b}}$ & $0.87^{\mathrm{b}}$ & -0.06 & $-0.64^{\mathrm{b}}$ & $-0.36^{\mathrm{b}}$ & $-0.73^{\mathrm{b}}$ \\
$\mathrm{SOC}$ & 0.12 & $0.24^{\mathrm{a}}$ & 0.18 & $0.30^{\mathrm{b}}$ & 0.07 & $0.37^{\mathrm{b}}$ \\
$\mathrm{TN}$ & $0.39^{\mathrm{b}}$ & $0.51^{\mathrm{b}}$ & 0.18 & -0.01 & 0.03 & 0.11 \\
$\mathrm{C}: \mathrm{N}$ & $-0.45^{\mathrm{b}}$ & $-0.44^{\mathrm{b}}$ & -0.11 & $0.60^{\mathrm{b}}$ & 0.02 & $0.44^{\mathrm{b}}$ \\
$\mathrm{NO}_{3}^{-}$ & $-0.24^{\mathrm{a}}$ & $-0.29^{\mathrm{b}}$ & $0.28^{\mathrm{b}}$ & -0.05 & 0.02 & 0.08 \\
$\mathrm{NH}_{4}^{+}$ & $-0.38^{\mathrm{b}}$ & $-0.33^{\mathrm{b}}$ & -0.10 & $0.46^{\mathrm{b}}$ & 0.15 & $0.63^{\mathrm{b}}$ \\
$\mathrm{TIN}_{\text {Olsen P }}$ & $-0.38^{\mathrm{b}}$ & $-0.39^{\mathrm{b}}$ & $0.19^{\mathrm{a}}$ & 0.17 & 0.08 & $0.36^{\mathrm{b}}$ \\
\hline
\end{tabular}

$\mathrm{a}^{\mathrm{a}}$ and ${ }^{\mathrm{b}}$ indicate significant levels at $P<0.05$ and 0.01 , respectively.

The $\mathrm{Zn}$ concentration was the highest at middle elevation for trees in leaves at wet temperate mountain (Fig. 4i), in roots at dry temperate mountain (Fig. 4j), in shoots at wet temperate mountain (Fig. 4k), and in stem sapwood at subtropical mountain (Fig. 41). With the increase in elevation, a decrease in $\mathrm{Zn}$ concentration was found in roots of trees at subtropical mountain (Fig. 4j) and in stem sapwood of shrubs at dry temperate mountain (Fig. 41); however, an increase in $\mathrm{Zn}$ was found in shrub roots at wet temperate mountain, in shoots of trees at dry temperate mountain and shrubs at wet temperate mountain (Fig. 4k), and in stem sapwood of trees at dry temperate mountain and shrubs at wet temperate mountain (Fig. 41).

\subsection{Correlations between plant and soil parameters}

Across all sampling sites and plant types, both soil exchangeable $\mathrm{Ca}$ and $\mathrm{Mg}$ were positively correlated with soil $\mathrm{pH}$ (Fig. S2a, b in the Supplement) and TN (Table 2), while they were negatively correlated with soil $\mathrm{C}: \mathrm{N}, \mathrm{NO}_{3}^{-}$, and $\mathrm{NH}_{4}^{+}$(Table 2). For wet temperate mountain, both soil $\mathrm{pH}$ and SOC showed no relationship with soil exchangeable $\mathrm{Ca}$ and $\mathrm{Mg}$ under tree canopies, although SOC was positively related to exchangeable K (Table S2). Negative correlations were found for both $\mathrm{Mg}$ and $\mathrm{K}$ concentrations between stems and leaves (both $p<0.01$; Table S3). However, $\mathrm{Mg}$ and $\mathrm{K}$ concentrations in roots showed no correlation with that in leaves (Table S3).

When analyzing data across sampling sites and plant types, soil-available Fe, Mn, and Zn were negatively correlated with soil $\mathrm{pH}(p<0.01$; Table 2, Fig. S2c, d, e), and soil-available Fe and $\mathrm{Zn}$ were positively correlated with SOC ( $p<0.01$; Table 2). However, available micronutrients had no relationships with either soil $\mathrm{pH}$ or SOC at dry temperate mountain, except for a positive correlation between soil $\mathrm{pH}$ and available Mn under shrub canopies (Table S2). For both $\mathrm{Mn}$ and $\mathrm{Zn}$ concentrations, significant and positive correlations were found between soil and plant tissues (Table S3).
Soil-available Fe was negatively correlated with Fe concentrations in shoots and stems (both $p<0.01$; Table S3).

According to the SEM analyses, soil $\mathrm{pH}$ and TN positively affected exchangeable $\mathrm{Ca}$, while $\mathrm{C}: \mathrm{N}$ negatively affected exchangeable $\mathrm{Ca}$ (Fig. 5a). Exchangeable $\mathrm{Mg}$ was positively affected by soil $\mathrm{pH}$ and $\mathrm{TN}$ (Fig. 5b). Soil $\mathrm{pH}, \mathrm{NH}_{4}^{+}$, and Olsen $\mathrm{P}$ explained $83 \%$ of the variance in exchangeable $\mathrm{K}$ (Fig. 5c). Soil-available Fe was negatively affected by soil $\mathrm{pH}$ and positively affected by SOC and C: N (Fig. 5d). Soil $\mathrm{pH}$ had negative effects on soil-available Fe (Fig. 5d), Mn (Fig. 5e), and Zn (Fig. 5f). A positive effect was detected for $\mathrm{C}: \mathrm{N}$ on soil-available Fe (Fig. 5d) and for $\mathrm{NH}_{4}^{+}$on both available Mn (Fig. 5e) and Zn (Fig. 5f). Soil pH indirectly affected exchangeable $\mathrm{Ca}$ and $\mathrm{Mg}$ as well as available $\mathrm{Fe}$ and Mn through changing soil $\mathrm{C}: \mathrm{N}$ (Fig. 5).

\section{Discussion}

\subsection{Elevational patterns of base cations and available micronutrients in soils and relationships with $\mathrm{pH}$ and SOC}

Contrary to our first hypothesis, no consistent elevational patterns were detected for soil exchangeable base cations and available micronutrients under either trees or shrubs. Inconsistent elevational patterns of soil base cations and available micronutrients indicated that plant uptake of these nutrients did not necessarily decrease more than nutrient supply at higher elevation due to more open canopies. Our results suggest that soil physio-chemical parameters were the dominant contributors and more important than environmental gradients affecting elevational patterns of soil exchangeable base cations and available micronutrients (Figs. 5 and S2). For instance, soil-available Fe, Mn, and $\mathrm{Zn}$ followed patterns of SOC under trees along the elevational gradient at subtropical mountain (Table S2), while for shrubs at subtropical mountain, soil $\mathrm{pH}$, instead of SOC, regulated elevational patterns of soil-available $\mathrm{Fe}, \mathrm{Mn}$, and $\mathrm{Zn}$ (Table S2). Our findings 

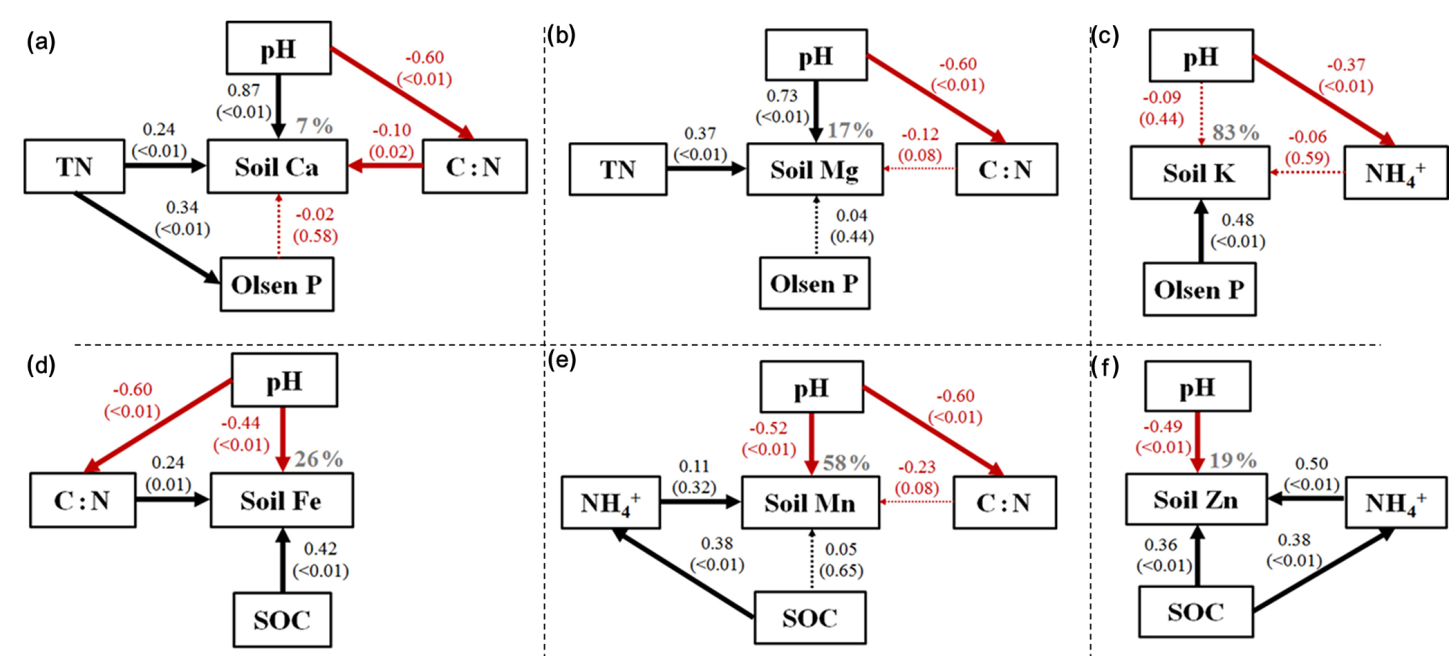

Figure 5. The results of structural equation modeling of the effect of soil parameters on soil exchangeable base cations of Ca, $\mathrm{Mg}$, and $\mathrm{K}$, and available micronutrients of $\mathrm{Fe}, \mathrm{Mn}$, and $\mathrm{Cu}$. Arrows indicate positive (black) and negative (red) effects. Solid and dotted lines represent significant and non-significant relationships, respectively. The number adjacent to each arrow is the standardized path coefficient with corresponding $p$ value in parentheses.

are consistent with a vast amount of previous studies confirming the pivotal role of soil $\mathrm{pH}$ and SOC concentration in determining soil base cation and micronutrient availabilities (Sharma et al., 2004; Lü et al., 2016; Wang et al., 2017). However, the fundamental roles of SOC and soil $\mathrm{pH}$ in controlling soil base cation and micronutrient availabilities was not universal, as suggested by the relatively weak relationships of soil $\mathrm{pH}$ and SOC with soil base cations under tree canopies at wet temperate mountain and with micronutrients under both tree and shrub canopies at dry temperate mountain (Table S2). This could indicate species- and type-specific effects on soil base cation and micronutrient availabilities.

Other soil parameters, such as $\mathrm{C}: \mathrm{N}$ and extractable $\mathrm{NO}_{3}^{-}$ and $\mathrm{NH}_{4}^{+}$also influenced the availability of base cations (Table 2 and Fig. 5). The soil $\mathrm{C}: \mathrm{N}$ ratio serves as an indicator of SOM decomposition status, where more decomposed SOM possesses a lower C : N ratio (Sollins et al., 2009) and a higher content of negatively charged functional groups (i.e., phenolic, carboxyl, and hydroxyl groups; Haberhauer et al., 1998). In this study, negative correlations between soil $C: N$ and base cations (Table 2) suggest that more decomposed SOM is beneficial for the retention of soil base cations. Furthermore, soil with a higher level of extractable $\mathrm{NO}_{3}^{-}$predisposes cations to leach accompanied by loss of $\mathrm{NO}_{3}^{-}$(Cremer and Prietzel, 2017). Therefore, significant negative correlations were detected between soil $\mathrm{NO}_{3}^{-}$and base cations in this study (Table 2). Soil extractable $\mathrm{NH}_{4}^{+}$was also negatively correlated with exchangeable $\mathrm{Ca}$ and $\mathrm{Mg}$, possibly because $\mathrm{NH}_{4}^{+}$can exchange with base cations on surface soil colloids into soil solution, thereby enhancing their loss (Wang et al., 2015; Cusack et al., 2016).
A negative correlation between soil $\mathrm{pH}$ and soil-available micronutrients (Table 2 and Fig. 5) might be due to precipitation of micronutrient cations at higher soil pH (Rengel, 2007). Indeed, solubility of micronutrients was suggested to decrease 100-fold (for $\mathrm{Mn}$ and $\mathrm{Zn}$ ) and 1000-fold (for $\mathrm{Fe}$ ) with a one unit increase in soil pH (Rengel, 2001). Soil organic matter plays an important role in micronutrient retention due to its negative charge (He et al., 2005; Wang et al., 2015, 2017). This may be a reason for the positive relationships between SOC and micronutrients (although not always significant; Table 2). While no general patterns were found for distribution of micronutrients under both tree and shrub canopies with elevation, our results suggest that the determinants of soil micronutrient availabilities were predominantly soil $\mathrm{pH}$ and SOC concentration, which are reflections of long-term climatic conditions, plant-soil interactions, and biogeochemical processes (Sinsabaugh et al., 2008).

\subsection{Elevational patterns of base cations and micronutrients in plants and plant-soil system}

In contrast to our second hypothesis, both trees and shrubs at higher elevation did not necessarily contain higher base cation and micronutrient concentrations in their tissues. No general patterns were found for base cations and micronutrients in both trees and shrubs along elevational gradients across the three sites (Figs. 3 and 4). Even upon normalizing the data to per unit concentration of soil-available nutrients, there were still no consistent elevational patterns for both base cations and micronutrients in plant tissues (Fig. S3). This suggests that base cation and micronutrient concentrations in plants are influenced by other factors besides elevation-induced changes in temperature, precipi- 
tation, specific nutrient absorption characteristics of different tissues, soil base cation and micronutrient availabilities, and other edaphic properties (Campo-Alves, 2003; Richardson, 2004). Another explanation could be that initial differences in soil properties (e.g., parent material) among climate zones were larger than the effects of elevation. Soil base cation and micronutrient availabilities were an important factor influencing their concentrations in plant tissues across all plant species and sampling sites (Table S3). Similar results were found for macronutrients (i.e., nitrogen and phosphorus) suggesting that "plants are what they root in" (Elser et al., 2010; Han et al., 2014). However, plant nutrients did not co-vary with soil nutrients along a $2200 \mathrm{~km}$ long climatic gradient in grasslands of northern China (Luo et al., 2015, 2016). The discrepancy of our study with Luo et al. (2015, 2016) might be driven by different ecosystem types (forest vs. grassland), dominant climatic factor gradients (temperature vs. precipitation), or different soil properties. The studies of Luo et al. $(2015,2016)$ were conducted in grassland ecosystems where precipitation played an essential role in nutrient concentrations in plant-soil systems. Moreover, base cation and micronutrient cycling processes are likely to be different between highly organic and fine-grained forest soils in our study versus less organic and sandy grassland soils in Luo et al. (2016). Inconsistent elevational patterns in plant nutrient concentrations could also be derived from the fact that individual plant species reinforced patterns of soil nutrient availabilities in their vicinity causing positive feedback between plant and soil (Hobbie, 1992).

The topic of base cation and micronutrient translocation in intact plants is important as it deals with the movement of micronutrients from root to the leaves during physiological activities, such as photosynthesis (Welch and Shuman, 1995). Also, it is an important process in determining plant chemical composition and subsequently litter quality, litter decomposition, and nutrient release (Sun et al., 2016). Given earlier findings that transport of base cations from roots to the leaves in woody plants is slow (van der Heijden et al., 2015), we found no significant correlation for both $\mathrm{Mg}$ and $\mathrm{K}$ between roots and leaves (Table S3). However, negative relationships of stem $\mathrm{Mg}$ vs. leaf $\mathrm{Mg}$ and stem $\mathrm{K}$ vs. leaf $\mathrm{K}$ suggest that the internal plant pools of base cations could act as sources of base cation supply for leaves (Weatherall et al., 2006). Translocation of base cations within plant tissues is one of the main physiological mechanisms buffering low nutrient availabilities in soils (van der Heijden et al., 2015). For instance, supplementation of $\mathrm{Mg}$ is a critical process for maintaining photosynthesis in forests growing on acidic and cation-poor soils (Verbruggen and Hermans, 2013). In support of this, we found significant positive correlations between $\mathrm{Mg}$ and soluble sugar concentrations (one of the main photosynthates) in leaves across the three sites (Fig. S4a), while relationships were more pronounced at wet temperate mountain (Fig. S4b), where soil $\mathrm{pH}$ and exchangeable $\mathrm{Mg}$ were the lowest (Figs. 1a, 2b).
Unlike $\mathrm{Ca}, \mathrm{Mg}, \mathrm{Mn}$, and $\mathrm{Zn}$, the concentrations of $\mathrm{K}$ and $\mathrm{Fe}$ in plant leaves decoupled with their availabilities in the soil (Table S3), which might suggest that it is not only the availability of these nutrients in soils which affects their leaf concentrations but that there are also other environmental factors (e.g., temperature) which play more important roles in affecting plant nutrition (van den Driessche, 1974). We do not know why this decoupling only occurred for $\mathrm{K}$ and $\mathrm{Fe}$, but it is possibly due to factors such as temperature-constrained soil microbial activity and plant metabolism (Körner and Paulsen, 2004) and subsequent uptake of these nutrients by plants. On the other hand, plants often increase nutrient uptake to compensate for decreased metabolism at low temperature (Reich and Oleksyn, 2004). Thus, these opposite effects of temperature on $\mathrm{K}$ and Fe concentrations in plant tissues may have obscured the relationships of $\mathrm{K}$ and $\mathrm{Fe}$ concentrations between plant leaves and soils along the elevational gradients. While plant nutrient concentrations were mainly influenced by nutrient availabilities in the soil and by internal plant translocation processes, we found no consistent evidence that plants accumulate more base cations and micronutrients in their tissues to better adapt to cold environments at higher elevation.

\section{Conclusions}

We did not find consistent elevational patterns of base cations and micronutrients in plant-soil systems along three different elevation transects up to the alpine tree and shrub lines in different regions of China. Rather, our results highlight the essential roles of specific edaphic properties of soil $\mathrm{pH}$, SOC, and extractable nitrate and ammonium in regulating soil base cation and micronutrient availabilities across climate zones. Soil-available base cations and micronutrients were mostly positively correlated with concentrations of base cations and micronutrients in plant tissues, except for $\mathrm{K}$ and Fe. Our results suggest that base cation and micronutrient concentrations in plants (trees and shrubs) growing at their upper limits are largely controlled by their availabilities in the soil rather than by plant adaptations to cold environments at higher elevations.

Data availability. Data sets for this paper can be obtained via personal communication with the corresponding author.

\section{The Supplement related to this article is available online at https://doi.org/10.5194/bg-15-1763-2018-supplement.}

Author contributions. MHL designed the study; XW, HL, JY, and $\mathrm{ZS}$ took plant and soil measurements; RW and XW analyzed the 
data; RW wrote the manuscript; MHL, FAD, and AC revised the manuscript; MHL and YJ provided funding and laboratory facilities for this study.

Competing interests. The authors declare that they have no conflict of interest.

Acknowledgements. The research behind this paper was financially supported by the National Natural Science Foundation of China (41371076, 31570501) and the Strategic Priority Research Program of the Chinese Academy of Sciences (XDB15010302).

Edited by: Michael Bahn

Reviewed by: three anonymous referees

\section{References}

Baribault, T. W., Kobe, R. K., and Finley, A. O.: Tropical tree growth is correlated with soil phosphorus, potassium, and calcium, though not for legumes, Ecol. Monogr., 82, 189-203, https://doi.org/10.1890/11-1013.1, 2012.

Barry, R. G.: Mountain weather and climate, Methuen, London and New York, 1981.

Campo-Alves, J.: Nutrient availability and fluxes along a toposequence with tropical dry forest in Mexico, Agrociencia, 37, 211219, 2003.

Cremer, M. and Prietzel, J.: Soil acidity and exchangeable base cation stocks under pure and mixed stands of European beech, Douglas fir and Norway spruce, Plant Soil, 415, 393-405, https://doi.org/10.1007/s11104-017-3177-1, 2017.

Cusack, D. F., Macy, J., and McDowell, W. H.: Nitrogen additions mobilize soil base cations in two tropical forests, Biogeochemistry, 128, 67-88, https://doi.org/10.1007/s10533-0160195-7, 2016.

Elser, J. J., Fagan, W. F., Kerkhoff, A. J., Swenson, N. G., and Enquist, B. J.: Biological stoichiometry of plant production: metabolism, scaling and ecological response to global change, New Phytol., 186, 593-608, https://doi.org/10.1111/j.14698137.2010.03214.x, 2010.

Haberhauer, G., Rafferty, B., Strebl, F., and Gerzabek, M. H.: Comparison of the composition of forest soil litter derived from three different sites at various decompositional stages using FTIR spectroscopy, Geoderma, 83, 331-342, https://doi.org/10.1016/S0016-7061(98)00008-1, 1998.

Han, X., Sistla, S. A., Zhang, Y., Lü, X., and Han, X.: Hierarchical responses of plant stoichiometry to nitrogen deposition and mowing in a temperate steppe, Plant Soil, 382, 175-187, https://doi.org/10.1007/s11104-014-2154-1, 2014.

He, Z., Yang, X., and Stoffella, P. J.: Trace elements in agroecosystems and impacts on the environment, J. Trace Elem. Med. Biol., 19, 125-140, https://doi.org/10.1016/j.jtemb.2005.02.010, 2005.

Hernandez-Apaolaza, L.: Can silicon partially alleviate micronutrient deficiency in plants? A review, Planta, 240, 447-458, https://doi.org/10.1007/s00425-014-2119-x, 2014.
Hobbie, S. E.: Effects of plant species on nutrient cycling, Trend. Ecol. Evol., 7, 336-339, https://doi.org/10.1016/01695347(92)90126-V, 1992.

IUSS Working Group WRB: World Reference Base for Soil Resource 2014, International soil classification system for naming soils and creating legends for soil maps. World Soil Resources Reports No. 106, FAO, Rome, 2014.

Körner, C. and Paulsen, J.: A world-wide study of high altitude treeline temperatures, J. Biogeogr., 31, 713-732, https://doi.org/10.1111/j.1365-2699.2003.01043.x, 2004.

Li, M.-H. and Yang, J.: Effects of elevation and microsite on growth of Pinus cembra in the subalpine zone of the Austrian Alps, Ann. For. Sci., 61, 319-325, https://doi.org/10.1051/forest:2004025, 2004.

Li, M.-H., Yang, J., and Kräuchi, N.: Growth responses of Picea abies and Larix decidua to elevation in subalpine areas of Tyrol, Austria, Can. J. Forest. Res., 33, 653-662, https://doi.org/10.1139/x02-202, 2003.

Li, M. H., Kräuchi, N., and Dobbertin, M.: Biomass distribution of different-aged needles in young and old Pinus cembra trees at highland and lowland sites, Trees, 20, 611-618, https://doi.org/10.1007/s00468-006-0076-0, 2006.

Li, M.-H., Xiao, W., Shi, P., Wang, S., Zhong, Y., Liu, X., Wang, X., Cai, X., and Shi, Z.: Nitrogen and carbon sourcesink relationships in trees at the Himalayan treelines compared with lower elevations, Plant Cell Environ., 31, 1377-1387, https://doi.org/10.1111/j.1365-3040.2008.01848.x, 2008a.

Li, M.-H., Xiao, W., Wang, S., Cheng, G., Cherubini, P., Cai, X., Liu, X., Wang, X., and Zhu, W.: Mobile carbohydrates in Himalayan treeline trees I. Evidence for carbon gain limitation but not for growth limitation, Tree Physiol., 28, 1287-1296, https://doi.org/10.1093/treephys/28.8.1287, 2008b.

Li, Z., Liu, G., Fu, B., Hu, C., Luo, S., Liu, X., and He, F.: Anomalous temperature-growth response of Abies faxoniana to sustained freezing stress along elevational gradients in China's Western Sichuan Province, Trees, 26, 1373-1388, https://doi.org/10.1007/s00468-012-0712-9, 2012.

Liptzin, D., Sanford Jr., R. L., and Seastedt, T. R.: Spatial patterns of total and available $\mathrm{N}$ and $\mathrm{P}$ at alpine treeline, Plant Soil, 365, 127-140, https://doi.org/10.1007/s11104-012-1379-0, 2013.

Lü, L., Wang, R., Liu, H., Yin, J., Xiao, J., Wang, Z., Zhao, Y., Yu, G., Han, X., and Jiang, Y.: Effect of soil coarseness on soil base cations and available micronutrients in a semi-arid sandy grassland, Solid Earth, 7, 549-556, https://doi.org/10.5194/se-7549-2016, 2016.

Lucena, J. J.: Effects of bicarbonate, nitrate and other environmental factors on iron deficiency chlorosis: A review, J. Plant Nutri., 23, 1591-1606, https://doi.org/10.1080/01904160009382126, 2000.

Luo, W., Elser, J. J., Lü, X., Wang, Z., Bai, E., Yan, C., Wang, C., Li, M.-H., Zimmermann, N. E., Han, X., Xu, Z., Li, H., Wu, Y., and Jiang, Y.: Plant nutrients do not covary with soil nutrients under changing climatic conditions, Global Biogeochem. Cy., 29, 1298-1308, https://doi.org/10.1002/2015GB005089, 2015.

Luo, W., Sardans, J., Dijkstra, F. A., Peñuelas, J., Lü, X., Wu, H., Li, M.-H., Bai, E., Wang, Z., Han, X., and Jiang, Y.: Thresholds in decoupled soil-plant elements under changing climatic conditions, Plant Soil, 409, 159-173, https://doi.org/10.1007/s11104016-2955-5, 2016. 
Maillard, A., Diquélou, S., Billard, V., Laîné, P., Garnica, M., Prudent, M., Garcia-Mina, J. M., Yvin, J. C., and Ourry, A.: Leaf mineral nutrient remobilization during leaf senescence and modulation by nutrient deficiency, Front. Plant Sci., 6, 317, https://doi.org/10.3389/fpls.2015.00317, 2015.

Mayor, J. R., Sanders, N. J., Classen, A. T., Bardgett, R. D., Clément, J. C., Fajardo, A., Lavorel, S., Sundqvist, M. K., Bahn, M., Chisholm, C., Cieraad, E., Gedalof, Z., Grigulis, K., Kudo, G., Oberski, D. L., and Wardle, D. A.: Elevation alters ecosystem properties across temperate treelines globally, Nature, 542, 91-95, https://doi.org/10.1038/nature21027, 2017.

Naples, B. K. and Fisk, M. C.: Belowground insights into nutrient limitation in northern hardwood forests, Biogeochemistry, 97, 109-121, https://doi.org/10.1007/s10533-009-9354-4, 2010.

Noble, I. R.: A model of the responses of ecotones to climate change, Ecol. Appl., 3, 396-403, https://doi.org/10.2307/1941908, 1993.

Oleksyn, J., Reich, P. B., Zytkowiak, R., Karolewski, P., and Tjoelker, M. G.: Needle nutrients in geographically diverse Pinus sylvestris L. populations, Ann. For. Sci., 59, 1-18, https://doi.org/10.1051/forest:2001001, 2002.

Olsen, S. R., Watanabe, F. S., Cosper, H. R., Larson, W. E., and Nelson, L. B.: Residual phosphorus availability in long-term rotations on calcareous soils, Soil Sci., 78, 141-152, 1954.

Qiang, W., Wang, X., Chen, T., Feng, H., An, L., He, Y., and Wang, G.: Variations of stomatal density and carbon isotope values of Picea crassifolia at different altitudes in the Qilian Mountains, Trees, 17, 258-262, https://doi.org/10.1007/s00468-002-0235-x, 2003.

Reisenauer, H. M.: Determination of plant-available soil manganese, in: Manganese in soils and plants, edited by: Graham, R. D., Hannam, R. J., and Uren, N. C., Kluwer Academic Publisher, Dordrecht, 87-98, 1988.

Reich, P. B. and Oleksyn, J.: Global patterns of plant leaf N and P in relation to temperature and latitude, P. Natl. Acad. Sci. USA, 101, 11001-11006, https://doi.org/10.1073/pnas.0403588101, 2004.

Rengel, Z.: Genotypic differences in micronutrient use efficiency in crops, Commun. Soil Sci. Plan., 32, 1163-1186, https://doi.org/10.1081/CSS-100104107, 2001.

Rengel, Z.: Cycling of micronutrients in terrestrial ecosystem, in: Nutrient cycling in terrestrial ecosystems, edited by: Marschner, P. and Rengel, Z., Springer-Verlag, Berlin, 93-113, 2007.

Richardson, A. D.: Foliar chemistry of balsam fir and red spruce in relation to elevation and the canopy light gradient in the mountains of the northeastern United States, Plant Soil, 260, 291-299, https://doi.org/10.1023/B:PLSO.0000030179.02819.85, 2004.

Salisbury, F. B. and Ross, C. W.: Mineral nutrition, in: Plant Physiology, Wadsworth Publishing Company, Belmont, 116-135, 1992.

Sardans, J. and Peñuelas, J.: Potassium: a neglected nutrient in global change, Global Ecol. Biogeogr., 24, 261-275, https://doi.org/10.1111/geb.12259, 2015.

Sharma, B. D., Arora, H., Kumar, R., and Nayyar, V. K.: Relationships between soil characteristics and total and DTPAextractable micronutrients in Inceptisols of Punjab, Commun. Soil Sci. Plan., 35, 799-818, https://doi.org/10.1081/CSS120030359, 2004.

Shen, C., Xiong, J., Zhang, H., Feng, Y., Lin, X., Li, X., Liang, W., and Chu, H.: Soil $\mathrm{pH}$ drives the spa- tial distribution of bacterial communities along elevation on Changbai Mountain, Soil Biol. Biochem., 57, 204-211, https://doi.org/10.1016/j.soilbio.2012.07.013, 2013.

Sinsabaugh, R. L., Lauber, C. L., Weintraub, M. N., Ahmed, B., Allison, S. D., Crenshaw, C., Contosta, A. R., Cusack, D., Frey, S., Gallo, M. E., Gartner, T. B., Hobbie, S. E, Holland, K., Keeler, B. L., Powers, J. S., Stursova, M., Takacs-Vesbach, C., Waldrop, M. P., Wallenstein, M. D., Zak, D. R., and Zeglin, L. H.: Stoichiometry of soil enzyme activity at global scale, Ecol. Lett., 11, 1252 1264, https://doi.org/10.1111/j.1461-0248.2008.01245.x, 2008.

Sollins, P., Kramer, M. G., Swanston, C., Lajtha, K., Filley, T., Aufdenkampe, A. K., Wagai, R., and Bowden, R. D.: Sequential density fractionation across soils of contrasting mineralogy: evidence for both microbial-and mineral-controlled soil organic matter stabilization, Biogeochemistry, 96, 209-231, https://doi.org/10.1007/s10533-009-9359-z, 2009.

Sun, T., Dong, L., Zhang, L., Wu, Z., Wang, Q., Li, Y., Zhang, H., and Wang, Z.: Early stage fine-root decomposition and its relationship with root order and soil depth in a Larix gmelinii plantation, Forests, 7, 234, https://doi.org/10.3390/f7100234, 2016.

Thébault, A., Clément, J. C., Ibanez, S., Roy, J., Geremia, R. A., Pérez, C. A., Buttler, A., Estienne, Y., and Lavorel, S.: Nitrogen limitation and microbial diversity at the treeline, Oikos, 123, 729-740, https://doi.org/10.1111/j.16000706.2013.00860.x, 2014.

Tian, Q., Liu, N., Bai, W., Li, L., Chen, J., Reich, P. B., Yu, Q., Guo, D., Smith, M. D., Knapp, A. K., Cheng, W., Lu, P., Gao, Y., Yang, A., Wang, T., Li, X., Wang, Z., Ma, Y., Han, X., and Zhang, W.: A novel soil manganese mechanism drives plant species loss with increased nitrogen deposition in a temperate steppe, Ecology, 97, 65-74, https://doi.org/10.1890/15-0917.1, 2016.

van den Driessche, R.: Prediction of mineral nutrient status of trees by foliar analysis, Bot. Rev., 40, 347-394, https://doi.org/10.1007/BF02860066, 1974.

van der Heijden, G., Dambrine, E., Pollier, B., Zeller, B., Ranger, J., and Legout, $\mathrm{A} .: \mathrm{Mg}$ and $\mathrm{Ca}$ uptake by roots in relation to depth and allocation to aboveground tissues: results from an isotopic labeling study in a beech forest on base-poor soil, Biogeochemistry, 122, 375-393, https://doi.org/10.1007/s10533-014-0047-2, 2015.

Verbruggen, N. and Hermans, C.: Physiological and molecular responses to magnesium nutritional imbalance in plants, Plant Soil, 368, 87-99, https://doi.org/10.1007/s11104-013-1589-0, 2013.

Wang, R., Dungait, J. A. J., Creamer, C. A., Cai, J., Li, B., Xu, Z., Zhang, Y., Ma, Y., and Jiang, Y.: Carbon and nitrogen dynamics in soil aggregates under long-term nitrogen and water addition in a temperate steppe, Soil Sci. Soc. Am. J., 79, 527-535, https://doi.org/10.2136/sssaj2014.09.0351, 2015.

Wang, R., Dungait, J. A. J., Buss, H. L., Yang, S., Zhang, Y., Xu, Z., and Jiang, Y.: Base cations and micronutrients in soil aggregates as affected by enhanced nitrogen and water inputs in a semi-arid steppe grassland, Sci. Total Environ., 575, 564-572, https://doi.org/10.1016/j.scitotenv.2016.09.018, 2017.

Wang, X., Cheng, G., Zhong, X., and Li, M. H.: Trace elements in subalpine forest soils on the eastern edge of the Tibetan Plateau, China, Environ. Geol., 58, 635-643, https://doi.org/10.1007/s00254-008-1538-z, 2009. 
Warnock, R. E.: Micronutrient uptake and mobility within corn plants (Zea mays L.) in relation to phosphorusinduced zinc deficiency, Soil Sci. Soc. Am. J., 34, 765-769, https://doi.org/10.2136/sssaj1970.03615995003400050028x, 1970.

Weatherall, A., Proe, M. F., Craig, J., Cameron, A. D., and Midwood, A. J.: Internal cycling of nitrogen, potassium and magnesium in young Sitka spruce, Tree Physiol., 26, 673-680, https://doi.org/10.1093/treephys/26.5.673, 2006.

Welch, R. M. and Shuman, L.: Micronutrient nutrition of plants, Crit. Rev. Plant Sci., 14, 49-82, https://doi.org/10.1080/07352689509701922, 1995.

White, J. G. and Zasoski, R. J.: Mapping soil micronutrients, Field Crop. Res., 60, 11-26, https://doi.org/10.1093/aob/mcg164, 1999.
Zhu, W., Xiang, J., Wang, S., and Li, M.-H.: Resprouting ability and mobile carbohydrate reserves in an oak shrubland decline with increasing elevation on the eastern edge of the Qinghai-Tibet Plateau, Forest Ecol. Manage., 278, 118-126, https://doi.org/10.1016/j.foreco.2012.04.032, 2012a.

Zhu, W., Cao, M., Wang, S., Xiao, W., and Li, M.-H.: Seasonal dynamics of mobile carbon supply in Quercus aquifolioides at the upper elevational limit, PLoS ONE, 7, e34213, https://doi.org/10.1371/journal.pone.0034213, 2012b. 